\title{
Expertise and the formation of university museum collections
}

\author{
Terje Brattli \& Morten Steffensen
}

\begin{abstract}
This text is a project presentation of work in progress. The objective is to introduce an alternative analytical approach to university museum collections as a phenomenon. This endeavour has been motivated by our experiences of the dynamic and multiple practices and versions of collections by these museums, rather than of the collections as static and uniform. Based on an approach inspired by ontological politics, we analyse the university museum collection as a result of different enactments rather than as a homogeneous entity that either just is, either passively observed or strategically and/or competitively constructed. These theoretical reflections, in addition to observations made in an initial empirical study of practices at a university museum, indicate the need to acknowledge the coexistence of several parallel versions of the university museum collection as expertise performance. This allows for the understanding of the university museum collection as multiple, and the second phase of this project will consist of analysis of relationships between various simultaneous practices and versions.
\end{abstract}

Keywords: University museum, museum collection, expertise, multiple reality, performativity.

The authors of this presentation were working at the NTNU University Museum when this study started. We were also participating in The Museum's Knowledge-Museum Knowledge (MusVit), a museology research network for Norwegian university museums, which aims to utilize and develop these museums' role as unique, independent, and powerful institutions of knowledge and communication.

Norwegian university museums are a significant part of the museum landscape in
Norway. They were all established during the nineteenth century, and have the preservation and presentation of and research on the natural and cultural history of Norway and the national regions as their core activity. The main disciplines were, and still are, biology, geology, and archaeology. The first university in Norway was Det kongelige Fredriks Universitet (today the University of Oslo), which was founded in 1811. Scientific collections and related practices soon became 
part of the activity of the new university. Later, during the twentieth century, other universities were established, and the regional museums with scientific collections became part of those new universities. Today, there are six university museums in Norway. Together, the university museums contain almost all (95\%) of the natural history collections in Norway. With regard to archaeology and cultural history, pursuant to the Cultural Heritage Act they have responsibility for a substantial part of the cultural heritage and remains that date before the Reformation (1536). This makes the university museums unique within a national context, and the collections they possess and manage are vast and with a wide distribution, both thematically and geographically. A Government White Paper titled Tingenes tale (St.meld nr. 15 (2007-08) states that university museums must have a holistic collection policy that relates to their priority areas for research, management, and communication. The Ministry of Education and Research will facilitate the development of each university museum's collection plans in accordance with the museum's priority areas for research, management, and communication. This implies that the university museums have a clear understanding of the nature of their collections. Our experience is that such a collection is not necessarily perceived in the same way in the context of research, management, and communication. An analysis of this issue is therefore necessary in the museums' efforts to achieve the Ministry's goal of a comprehensive collection policy.

This raises the question of what we actually mean when we talk about the university museum collection. Does the collection define the nature of the university museum or vice versa? How we answer these questions will depend on the way we understand the nature of knowledge. One way to investigate this issue is by analysing the relationship between expertise (i.e. how different museum activities are practised) and the museum collection (i.e. accumulated objects held in storage within the museum). We believe that connecting these elements is appropriate in order to contribute to an understanding of (1) how and what the museum collection as a phenomenon becomes and why, and (2) whether and why certain versions of the phenomenon gain hegemony and/or preferability. The nature of this connection point is also crucial. In recent years, research focusing on museum practices - or doing has increased (Macdonald 2006, Brenna 2012, Maurstad \& Hauan 2012). This opens up for doing, or rather performativity, as an approach to aspects of museums. In this presentation we therefore want to introduce an analytical approach to the museum collection as a phenomenon by analysing the nature of the collection as an intersection between expertise, knowledge, and material, and where the intersection is performativity. In other words, we want to contribute to the identification and description of a field for interaction. The aim is to explore how a study of practices can help us understand the nature of the museum collection as well as the museum as an arena for the constitution of knowledge.

Although we believe that this approach may be applicable for museums in general, we have in mind the university museum in particular. As institutions, the university museums differ from other types of museums in the museum landscape. The fact that they are parts of universities makes them to a greater extent 
also institutions of research. This implies the presence of a number of actors - in this sense as experts - that are not in the same degree present in other museum contexts. Nevertheless, the museum collection is something that the university museums have in common with most other museums, and it is here as elsewhere considered a central element, if not the very core of the museum. Moreover, the museum collection is an important element in the constitution of these institutions, which also makes them different from other units at the universities to which they belong. Without their collections, the university museums would probably not exist as such, yet the collections do not make these museums correspond to the museums in general. This is not only because they collect different types of objects, but also because we are dealing with different constellations of experts, in which researchers are more significant for the university museums. In accordance with our analytical approach to the museum collection as a phenomenon presented above, we therefore assume that the performances related to the stored objects in the university museum make their collections distinctively different from those we find in museums in general.

\section{THE MUSEUM COLLECTION AS A MANIFOLD PHENOMENON}

The analytical approach of this presentation is the result of a process where we started out by reflecting on the nature of the scientific collection. As staff members at a university museum we experienced that different versions of the collection seemed to coexist through the university museum's everyday practices. Through discussions on this issue and with the help of a mind map (fig. 1) we have formulated what we thus far characterize as three postulates:

1. The collection is more than an accumulation of objects.

2. The collection has agency.

3. Research and other practices have been separated.

The first postulate raises yet another question: If the collection is more than an accumulation of objects, what then is its nature? The second postulate implies that the collection is both acted upon and in itself produces effects, and is thereby defined through networks and practices. The third postulate is a result of the appreciation that the development of the collection and the practices connected to it has shifted from being relatively homogeneous, to having an increasing degree of heterogeneity and complexity. Further, the question is whether this has led to a more manifold performativity and thus a multiplication of the collection.

Where does this leave us when it comes to analysing and establishing an understanding of the museum collection as a phenomenon? In the following, we briefly present an analytical approach to the issue that we find appropriate for capturing the heterogeneity that characterizes the current museum practices related to the collections.

This implies that the museum collection has to be explored as a manifold phenomenon, rather than just as an accumulation of objects held in storage, itself constituting Reality, with a capital " $R$ ". However, this epistemological stance is far from new. Perspectivalism and constructivism have both been applied in opposition to this traditional understanding of truth, for instance in new museology. Common features of this way of thinking are 


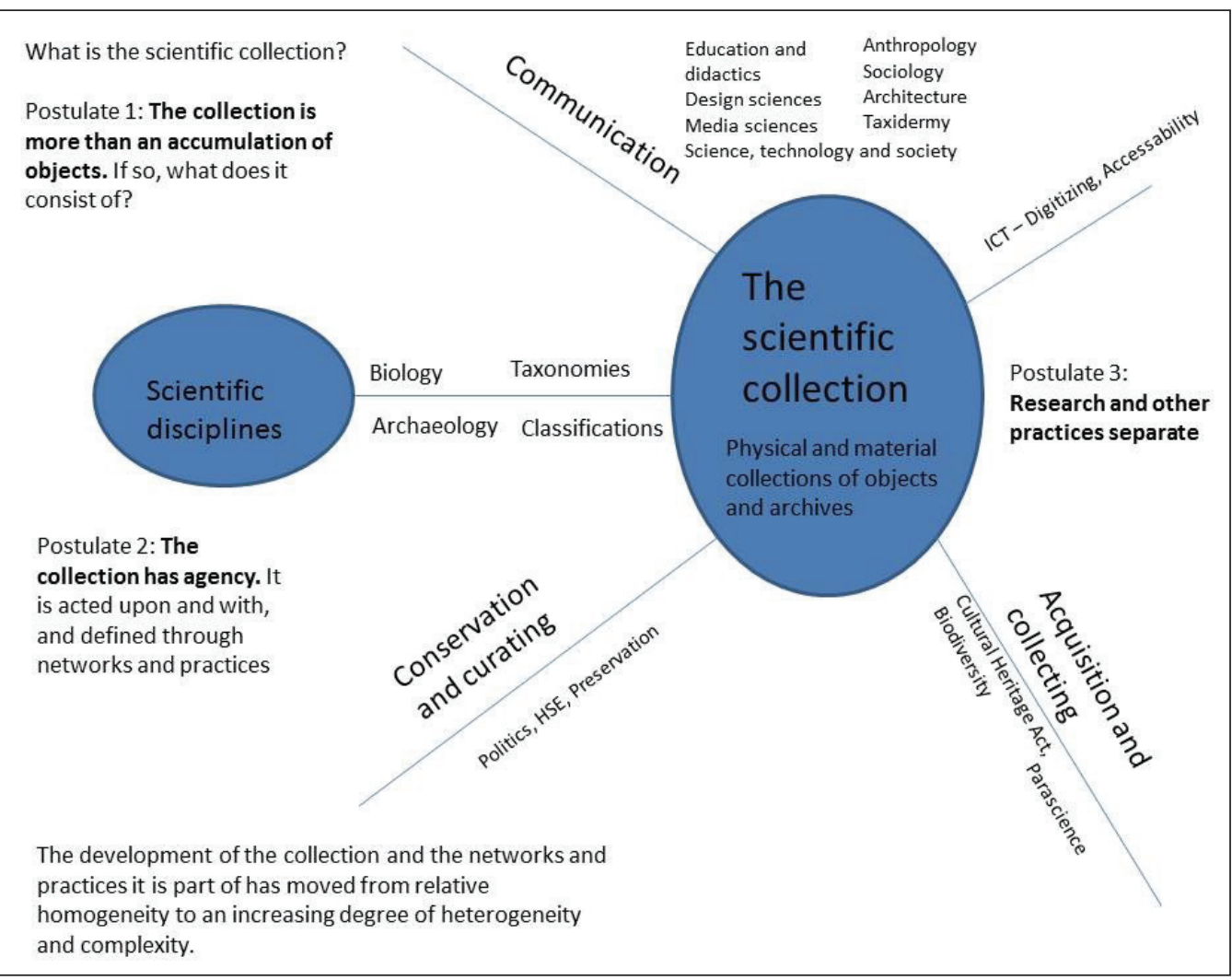

Fig. 1. Mind map of a museum collection.

to understand the meaning of museum objects as situated and contextual rather than inherent, and how the museum and its exhibitions may be variously perceived (Macdonald 2006). In our view, the result of such an approach is pluralism. However, perspectivalism does not create a multiple reality, it just multiplies the eyes of the beholders. Further, constructivism claims that alternative constructions of reality that might have been possible in the past somehow lost in the competition against the current construction and then vanished. Competing constructions undermine each other and therefore cannot coexist as realities within shared contexts. This is plurality in a time perspective: the winner takes it all $(\mathrm{Mol}$ 1999).

Based on our experience as staff members at a university museum, we think that pluralism does not take us far enough in exploring the possible manifold character of the museum collection. The reason is that the museum collection seems to be different phenomena or realities coexisting both in time and for individuals, thus having what $\mathrm{Mol}$ denotes as 
multiple existence. What, then, is the university museum collection? It is source of production of knowledge of past societies and nature. It is legislative practice. It is administration with regard to security, economy, and organization. It is bulky matter also subject to physical deterioration that must be stopped or limited. It is communication. Pluralism either reduces all this to just aspects of the museum collection as a single reality, still comprising some kind of core with an intrinsic essence, or it appoints one of the versions to reality as the victorious construction. This does not help us towards an understanding of the phenomenon as multiple realities. In this respect, there is a significant difference. Perceiving reality as multiple rather than plural makes possible the coexistence of different realities within shared contexts. Moreover, we understand the university museum as such a shared context, where different versions of the museum collection are performed simultaneously every day, and in some cases even by the same individuals - sometimes in conflict with each other, sometimes dependent upon each other, and sometimes even embedded in each other (Mol 1999, Law 2007).

\section{REALITY AS PERFORMED}

If the museum collection is several phenomenon simultaneously (multiple realities), how then could this come to be? Inspired by Annemarie Mol and her article on ontological politics (1999), our analytical approach to the museum collection as a multiple phenomenon is based on performativity. On this basis we present an outline or idea for a study of how different types of practices at the university museums interact with the museum collection and thereby create different versions. These practices represent different activities, such as science/research, conservation, administration/management, and communication. We do not focus on what different perspectives actors within these activities may have on the museum collection, nor do we approach the museum collection as a constructed phenomenon. Instead, the museum collection is understood as done rather than observed. Since our hypothesis is that different kinds of museum practices perform different versions of the museum collection, the concept of expertlexpertise becomes important, and we also understand this in a wide sense. Expertise is not constrained to just traditional academic knowledge used in museums, such as archaeology, biology, and so forth. Also, expertise means more than technological skills relevant for the preservation of objects. Further, our definition goes beyond pedagogical and artistic know-how relevant for museum communication. In addition to all these aspects, expertise in our sense of the word also includes practices related to museum management, administration, and economy.

In order both to investigate whether our approach to the problem area is appropriate and to answer the questions that were put forward in the introduction, it is necessary to conduct a survey of practices at the university museum. In order to achieve this, a focus group consisting of representatives from the different fields of expertise - communication, management/administration/economy, conservation, and research - defined at the university museum at NTNU has been established. The first workshop has been held and involved the formulation of a description of practice. Preliminary analyses of the results from this workshop show that the four 
activities relate to the museum collection in very different ways, especially when it comes to what the practitioners regard as their key activity. Although this was not unexpected, it was still necessary to hear from the practitioners themselves. It also shows a possible outline of different performance stories regarding the museum collection, which for us is a crucial analytical pivot point. The conservation group focuses on the preservation and securing of the objects with legislative protection; the collection becomes physical matter where chemical processes run their course. The management/administration/ economy group puts forward as their key activities strategic thinking, external relations, communication, measures for securing, use of resources, management of personnel, counselling, planning, and reporting; the collection becomes bureaucracy and politics. The communication group focuses on making the collection available for the public through exhibitions and through teaching schoolchildren; the collection becomes communication. The group of researchers puts forward production of knowledge, preferably new knowledge; the collection becomes knowledge of past societies and nature.

In analysing Annemarie Mol's book titled The Body Multiple: Ontology in Medical Practice from 2002, John Law (2009:152) concludes: "In theory the body may be single but in practice it is multiple because there are many body practices and therefore many bodies" (emphasis in original). Our preliminary results of the practices related to the university museum collection can be formulated in a similar manner. We experience that in theory the collection may be single, but in practice is multiple because there are many collection practices and thus many collections.

\section{DisCUSSION}

Although thus far we have executed only the first step in our investigation, and our analyses of the results are far from complete, we already at this point want to present some of our reflections on the implications of our findings. Although focusing on performance rather than perspectivalism or constructivism opens up for the appreciation of coexisting realities, we see that our results are likely to draw a picture of hegemony and dominance as preferred activities - when it comes to performance of expertise. One important factor in this respect is that the university museums are institutions obliged to fulfil a social mission. The content of the mission is not defined or decided by the university museums themselves, but is embodied in policy documents that these institutions must relate to. This and other factors contribute to designating activities at the university museums as basic or constitutive. Some performance stories, and hence also some versions of the museum collection, may thus be likely to become preferred versions, although still coexisting with other versions. One example to consider is that changes in policy, such as more emphasis on public access and communication, may have implications for the definition of the university museums' purpose. This indicates that we may be dealing with a dynamic and negotiable state that contributes to the movability of ontologies.

It may therefore be appropriate to promote the following (but preliminary) hypothesis: Preferred versions of the university museum collection are dependent on what the main purpose of university museum is at all times. In the following, we try to justify this hypothesis. 
If, for example, knowledge production of past societies and nature is designated as the main activity (i.e. what the university museum primarily is about), the performance stories of, for example, conservation and that version may be marginalized. Expertise decides reality, not by detecting it but by doing it. The result is that the kind of expertise regarded as most relevant may be decisive to a considerable degree for what version of the museum collection becomes the preferred version. If so, the power to define the institution's very purpose will also have a significant impact on the museum collection as reality. Here, we believe we can see an outline of a possible room for contradictions and ongoing negotiations. The element that is about politics in the sense of ontological politics makes it all a matter of choice and consequences. The museum collection has a movable ontology that is conditional also on policy choices. Compared with other kinds of museums, the university museum is composed of different types of expertise and has different purposes. Based on our epistemological approach, this inevitably paves the way for versions of museum collections that are exclusive to the university museums.

However, prioritizing research will not lead to deconsolidation of the conservation version of the museum collection altogether, as conservation still continues to be performed. This is largely due to the circumstance that in most cases conservation is also essential for the performance of research. Yet, it is probably not possible in an ontological politics context to claim that conservation of the objects held in storage does not perform a version of the collection also beyond research on past and nature, although this occurs in close relation to these activities. Further, even if the stored objects are neither related to research nor 101 related to conservation in any way, they still may be performed and therefore constitute a version of the museum collection. However, without doing, there is no being, just an accumulation of things. In other words, without expertise there is no museum collection, only the retention of objects.

\section{CONCLUSION}

Through ontological politics our objective is to analyse the university museum collection as something that is done, rather than something that just is, passively observed or strategicl competitively constructed. The aim of this presentation has been to describe the nature of this approach and its analytical potential for understanding the character of the university museum, the museum collection, the expertise, and the relationships between them. We find this approach fruitful because it allows for multiple, simultaneously existing versions of the museum collection that also coexist. The reason for this is that it is precisely this form of coexistence that we experience through the university museum's daily practices. Neither perspectivalism nor constructivism captures this coexistence in a manner that allows sufficiently relevant analyses, whether of the museum collection or of the university museum and the expert function. We believe that the character of the university museum is reflected in the mechanisms underlying the formations of the museum collection and vice versa. Throughout this presentation we have attempted to outline the course that our future work will follow. 


\section{LITERATURE}

Brenna, Brita 2012. "Gjort er gjort.” In Anita Maurstad \& Marit Anne Hauan (eds.). Museologi på norsk: Universitetsmuseenes gjøren. Trondheim: Akademika forlag, 231-237.

Law, John 2009. "Actor network theory and material semiotics." In Bryan S. Turner (ed.). The New Blackwell Companion to Social Theory. Chichester: Blackwell Publishing Ltd, 141-158. Maurstad Anita \& Hauan, Marit Anne 2012. “Universitetsmuseenes gjøren.” In Anita Maurstad \& Marit Anne Hauan (eds.). Museologi på norsk: Universitetsmuseenes gjøren. Trondheim: Akademika forlag, 13-31.

Macdonald, Sharon 2006. "Expanding museum studies: An introduction." In Sharon Macdonald (ed.). A Companion to Museum Studies. Malden: Blackwell, 1-12.

Mol, Annemarie 1999. "Ontological politics: A word and some questions." In John Law \& John Hassard (eds.). Actor Network Theory and After. Oxford: Blackwell Publications, 74-89.

St.meld. nr. 15 (2007-08) Tingenes tale: Universitetsmuseene. Oslo: Ministry of Education and Research.
Terje Brattli, researcher/postdoc

terje.brattli@ntnu.no

Department of Archaeology and Cultural history

NTNU University Museum

NO-7491 Trondheim, Norway

Morten Steffensen, director/Ph.D. student

morten.steffensen@nordlandsmuseet.no

Nordlandsmuseet, Prinsens gt. 116

NO-8005 Bodø, Norway

Department of Interdisciplinary Studies of Culture

NTNU University Museum

NO-7491 Trondheim, Norway

\section{ACKNOWLEDGEMENTS}

Thanks to Jon Anders Risvaag, Morten Sylvester and Torkild Bakken for comments on earlier versions of the text, as well as for cooperation in the planning and implementation of the workshop. 